\title{
Rekultywacja w projekcie robót geologicznych
}

\section{Wstęp}

Skutkiem działalności zakładów górniczych jest $\mathrm{z}$ reguły doprowadzenie do powstania niekorzystnych zmian $\mathrm{w}$ środowisku, w tym przede wszystkim w gruncie ${ }^{1}$. Mając to na uwadze, ustawodawca nałożył na podmioty likwidujące zakłady górnicze obowiązek podejmowania czynności służących usuwaniu zaistniałych szkód w gruncie, czyli przeprowadzenia tzw. rekultywacji. W literaturze przedmiotu wskazuje się wprost, że „sposób likwidacji zakładu górniczego określany jest poprzez kierunek rekultywacji”2.

Cel rozważań zawartych w tym artykule stanowi zbadanie wymogów dotyczących przedstawiania planów prac rekultywacyjnych jeszcze przed przystąpieniem do wykonywania właściwej działalności geologicznej. Chodzi tutaj o analizę zasad realizacji tego wymogu w treści dokumentu określonego w art. 79 ustawy z dnia 9 czerwca 2011 r. - Prawo geologiczne i górnicze ${ }^{3}$ jako projekt robót geologicznych.

${ }^{1}$ Zob. J. Bednorz: Społeczno-ekologiczne skutki eksploatacji wegla kamiennego w Polsce. „Górnictwo i Geologia” 2011, T. 6, z. 4, s. 5-17.

${ }^{2}$ U. Kaźmierczak: Efektywność waloryzacji terenów poeksploatacyjnych górnictwa skalnego. Politechnika Wrocławska, Wrocław 2019, s. 71.

${ }^{3}$ T.j. z dnia 26 marca 2020 r. (Dz.U. 2020, poz. 1064 ze zm.); dalej: pr.g.g. 


\section{Obowiązek rekultywacyjny}

Na wstępie trzeba zaznaczyć, że w ramach regulacji pr.g.g. nie ujęto definicji pojęcia „rekultywacja”. Na podstawie treści postanowień tej ustawy można jedynie wywnioskować, iż przez wspomniane pojęcie rozumieć należy pojedyncze działanie albo zespół czynności, które powinny zostać podjęte po zlikwidowaniu zakładu górniczego (art. 129 ust. 1 pkt 5 pr.g.g.) ${ }^{4}$. Równocześnie zgodnie z art. 129 ust. 2 pr.g.g. do rekultywacji gruntów na podstawie owej ustawy stosuje się odpowiednio przepisy ustawy z dnia 3 lutego 1995 r. o ochronie gruntów rolnych i leśnych ${ }^{5}$. W konsekwencji przyjąć więc trzeba, iż dokonując interpretacji pr.g.g. i posługując się jego poszczególnymi postanowieniami odnośnie do rekultywacji, odwoływać się powinno do definicji tego pojęcia, która została ujęta $\mathrm{w}$ treści u.o.g.r.1. ${ }^{6}$

W związku z powyższym, stosownie do art. 4 pkt 18 u.o.g.r.l., przez rekultywację rozumieć należy nadanie lub przywrócenie gruntom zdegradowanym albo zdewastowanym wartości użytkowych lub przyrodniczych przez właściwe ukształtowanie rzeźby terenu, poprawienie właściwości fizycznych i chemicznych, uregulowanie stosunków wodnych, odtworzenie gleb, umocnienie skarp oraz odbudowanie lub zbudowanie niezbędnych dróg. W tym kontekście warto podkreślić trafną uwagę J. Bieluka, zgodnie z którą „rekultywacja dotyczyć może wyłącznie gruntów rolnych lub leśnych"”. W doktrynie wyjaśnia się również, że „rekultywację można podzielić na techniczną i biologiczną. Na rekultywację techniczną składają się następujące czynności: ukształtowanie rzeźby terenu, uregulowanie stosunków wodnych, odtwarzanie gleby metodami technicznymi, budowa dróg dojazdowych i umacnianie skarp. Rekultywacja biolo-

${ }^{4}$ Więcej na ten temat - zob. M. Ptak, Z. Kasztelewicz: Proces likwidacji, rekultywacji w odkrywkowych zakładach górniczych a wykorzystanie odpadów wydobywczych, innych niż wydobywcze oraz surowców antropogenicznych. „Górnictwo Odkrywkowe” 2016, R. 57, nr 1, s. $42-43$.

${ }^{5}$ T.j. z dnia 26 maja 2017 r. (Dz.U. 2017, poz. 1161 ze zm.); dalej: u.o.g.r.l. W kontekście przedstawionego odesłania pojawia się problem organów właściwych w sprawie rekultywacji, owo zagadnienie przekracza jednak ramy niniejszego opracowania. Więcej na ten temat - zob. M. Walas: Administracja geologiczna i górnicza. W: Wybrane problemy prawa geologicznego i górniczego. Red. B. Rakoczy. LEX 2016.

${ }^{6}$ Warto zauważyć konsekwencję ustawodawcy w tym zakresie. W poprzednim stanie prawnym, tj. pod rządami ustawy z dnia 4 lutego 1994 r. - Prawo geologiczne i górnicze (Dz.U. 1994, nr 27, poz. 96, t.j. z dnia 22 listopada 2005 r.), w przedmiocie rekultywacji istniało odesłanie do tej samej ustawy (zob. R. Mikosz: Odpowiedzialność za szkody wyrzadzone ruchem zakładu górniczego. Wolters Kluwer, Zakamycze 2006, LEX.

7 J. Bieluk: Komentarz do art. 4. W: Ustawa o ochronie gruntów rolnych i leśnych. Komentarz. Red. J. Bieluk, D. Łobos-Kotowska. Legalis 2015. 
giczna sprowadza się do stosowania zabiegów, które mają na celu wytworzenie na powierzchni nieużytku warstwy gleby"s.

Analizując brzmienie przywołanej definicji pojęcia „rekultywacja”, można zauważyć, że na jej treść składają się w głównej mierze zwroty niedookreślone (np. „umacnianie skarp”), których znaczenia nie doprecyzowano w u.o.g.r.l. W tekście ustawy nie ma również mowy o tym, by organy nadzorujące rekultywację były wyposażone w kompetencje do szczegółowego wyznaczania jej przebiegu, m.in. do określania prac, jakie powinny zostać wykonane 9 . W tym kontekście w doktrynie podnosi się, że „katalog przedsięwzięć wymienionych w przedmiotowej definicji nie musi być jednak zrealizowany w całości przez przedsiębiorcę, a poszczególne działania rekultywacyjne muszą być dostosowane do zniszczeń gruntu. Stąd definicja ta nie ma charakteru instrumentalnego, lecz celowościowy. Wskazuje ona przede wszystkim cel, jaki należy osiągnąć, stosując rekultywację terenu: nadanie lub przywrócenie gruntom wartości użytkowych lub przyrodniczych"10. W konsekwencji więc to podmiot zobowiązany do przeprowadzenia działań rekultywacyjnych jest uprawniony do samodzielnego określenia sposobu ich realizacji, a jedyną wytyczną przy doborze konkretnych prac stanowi to, że mają się one przyczyniać do realizacji wspomnianego wcześniej celu rekultywacji. Niemniej w doktrynie zastrzega się, iż , rzemiosło tych prac jest [...] przedmiotem norm technicznych (Polska Norma PN-G$-7800: 2002)^{\prime \prime 11}$. W związku z tym zauważyć należy, że zgodnie z art. 5 ust. 3 ustawy z dnia 12 września 2002 r. o normalizacji12 stosowanie Polskich Norm jest dobrowolne; ponadto ani regulacje u.o.g.r.l., ani postanowienia pr.g.g. nie stanowią o nakazie korzystania $\mathrm{z}$ nich $\mathrm{w}$ procesie rekultywacji ${ }^{13}$. W rezultacie pogląd mówiący o związaniu prowadzącego rekultywację regulacjami jednej z Polskich Norm uznać trzeba za błędny.

Co istotne, sam obowiązek rekultywacyjny powstaje, stosownie do art. 20 ust. 1 u.o.g.r.l., w następstwie zdegradowania albo zdewastowania gruntu, czyli zmniejszenia jego rolniczej lub leśnej wartości użytkowej albo pozbawienia go tej wartości, zwłaszcza w wyniku pogorszenia się warunków przyrodniczych bądź wskutek zmian środowiska oraz działalności przemysłowej, a także niewłaściwie wykonywanej działalności rolniczej. Dodatkowo w przywołanej usta-

${ }^{8}$ P. Korzeniowski: Cele i funkcje ochrony prawnej gruntów rolnych i leśnych. „Prawo i Środowisko" 2012, nr 3, s. 111- 124. Na temat wyodrębnienia poszczególnych etapów rekultywacji zob. także Z. Prusinkiewicz, A. Kowalkowski, L. Królikowski: Ochrona i rekultywacja gleb leśnych. „Roczniki Gleboznawcze” 1983, T. 34, nr 3, s. 196-197.

${ }^{9} \mathrm{Na}$ temat rekultywacji zob. także W. Radecki: Rekultywacja zanieczyszczonej ziemi. „Ochrona Środowiska. Prawo i Polityka” 2007, nr 3 (49), s. 49-53.

${ }^{10}$ P. Wojtulek, T. Kocowski, W. Małecki: Prawo geologiczne i górnicze. Wydawnictwo C.H. Beck, Warszawa 2020, s. 264.

${ }^{11}$ Ibidem, s. 265.

12 T.j. z dnia 8 września 2015 r. (Dz.U. z 2015 r. poz. 1483).

${ }^{13}$ Zob. wyrok NSA z dnia 13 lutego 2019 r., sygn. II OSK 641/17, Legalis nr 1889827. 
wie „wprowadzono obowiązek rekultywacji i zagospodarowania gruntów na wszystkich etapach działalności przemysłowej” ${ }^{14}$. Ponadto, tak jak w uprzednim stanie prawnym, „obowiązek rekultywacji powstaje z mocy prawa"15.

W kontekście przytoczonego wyżej przepisu zaznaczyć również trzeba, że ustawodawca nie określa innych przesłanek przemawiających za przypisaniem odpowiedzialności za przeprowadzenie prac rekultywacyjnych poza tymi, które zostały wskazane w treści art. 20 ust. 1 u.o.g.r.l. Należy zatem przyjąć, iż obciążenie obowiązkiem rekultywacyjnym sprawcy zdegradowania albo zdewastowania gruntu następuje niezależnie od przyczyn i stopnia ingerencji w jego wartość użytkową. Co więcej, ustawodawca nie wiąże obowiązku przeprowadzenia rekultywacji z posiadaniem tytułu prawnego do gruntu ${ }^{16}$.

Biorąc powyższe pod uwagę, trzeba podkreślić, że w treści art. 129 pr.g.g. ujęta została ogólna zasada, zgodnie z którą wykonanie prac rekultywacyjnych obciąża każdego przedsiębiorcę likwidującego zakład górniczy. Na tej podstawie można więc zauważyć, że ustawodawca w pr.g.g. - inaczej aniżeli w przypad$\mathrm{ku}$ wspomnianych regulacji u.o.g.r.l. - określił konkretne przymioty podmiotu odpowiedzialnego za rekultywację, tj. bycie przedsiębiorcą oraz likwidowanie zakładu górniczego. Pomimo to nie wydaje się, by przywołane postanowienie pr.g.g. stanowiło lex specialis $\mathrm{w}$ stosunku do art. 20 ust. 1 u.o.g.r.l. De facto bowiem działalność gospodarcza opierająca się stricte na prowadzeniu zakładu górniczego będzie w oczywisty sposób negatywnie oddziaływała na wartość użytkową gruntu, a więc będzie skutkowałam powstaniem obowiązku rekultywacyjnego również w rozumieniu art. 20 ust. 1 u.o.g.r.l.

${ }^{14}$ J. Ciechanowicz-McLean, K. Wysokińska: Prawna ochrona gruntów rolnych i leśnych. W: Administracja a środowisko: prace dedykowane prof. zw. dr. hab. Markowi Górskiemu z okazji jubileuszu 45-lecia pracy naukowej. Red. A. Barczak, P. Korzeniowski. Wydawnictwo Naukowe Uniwersytetu Szczecińskiego, Szczecin 2018, s. 166.

${ }^{15}$ D. Trzcińska: Szkoda w środowisku zaistniała przed wejściem w życie ustawy z 13 kwietnia 2007 r. o zapobieganiu szkodom w środowisku i ich naprawie. W: Prawne aspekty gospodarowania zasobami środowiska. Oddziaływanie na zasoby środowiska. Red. B. Rakoczy, M. Szalewska, K. Karpus. TNOiK „Dom Organizatora”, Toruń 2014, s. 121. Na temat uregulowania rekultywacji w ramach uprzedniego stanu prawnego zob. E.K. Czech: Obowiąki rekultywacji $i$ remediacji powierzchni ziemi jako obowiazki wynikajace z mocy samego prawa - ocena istniejacych $i$ proponowanych rozwiązań prawnych. W: Prawne aspekty gospodarowania..., s. 195-203.

${ }_{16}$ Zob. wyrok WSA w Gliwicach z dnia 15 stycznia 2010 r., sygn. II SA/Gl 1334/08, Legalis nr 380970 . 


\section{Projekt robót geologicznych}

Wyjaśnienie pojęcia „projekt robót geologicznych” zostało w pr.g.g. sprowadzone do przedstawienia zawartości tego dokumentu. Otóż zgodnie z art. 79 ust. 2 pr.g.g. projekt robót geologicznych określa w szczególności:

1) cel zamierzonych robót oraz sposób jego osiągnięcia;

2) rodzaj dokumentacji geologicznej mającej powstać w wyniku robót geologicznych;

3) harmonogram robót geologicznych;

4) przestrzeń, w której obrębie mają być wykonywane roboty geologiczne;

5) przedsięwzięcia konieczne ze względu na ochronę środowiska, w tym wód podziemnych, sposób likwidacji wyrobisk, otworów wiertniczych, rekultywacji gruntów, a także czynności mające na celu zapobieżenie szkodom powstałym wskutek wykonywania zamierzonych robót.

Niewątpliwie ze względu na zastosowanie w treści przywołanego art. 79 ust. 2 pr.g.g. zwrotu „W szczególności” nie można powiedzieć, że określa on minimalny zakres treści, jakie powinny zostać ujęte w projekcie robót geologicznych $^{17}$. Z tej perspektywy nie wydaje się więc jasne, czy w przypadku każdego projektu konieczne jest zamieszczenie informacji o rekultywacji. W świetle powyższego warto zauważyć, iż stosownie do art. 79 ust. 1 pr.g.g. projekt robót geologicznych jest przygotowywany wyłącznie na potrzeby prac geologicznych prowadzonych z zastosowaniem robót geologicznych ${ }^{18}$. Z kolei zgodnie $\mathrm{z}$ art. 6 ust. 1 pkt 11 pr.g.g. przez to ostatnie pojęcie rozumieć należy wykonywanie w ramach prac geologicznych wszelkich czynności poniżej powierzchni terenu, w tym z użyciem środków strzałowych, a także likwidację wyrobisk po tych czynnościach. Można zatem powiedzieć, iż „roboty geologiczne” oznaczają każde działanie podejmowane $\mathrm{w}$ ramach prac geologicznych, które może być realizowane na dowolnej głębokości gruntu ${ }^{19}$, czyli również prace podziemne ${ }^{20}$. Z kolei jeśli weźmie się pod uwagę zarówno specyfikę, jak i cele takich działań, uzasadnione będzie twierdzenie, iż każdy rodzaj robót geologicznych wiąże się z negatywnym oddziaływaniem na wartość użytkową lub przyrodniczą grun-

17 „Odnosząc się do wymogów formalnych, jakie powinien spełniać projekt robót geologicznych, wskazać należy, iż art. 79 ust. 2 nie zawiera zamkniętego katalogu elementów składowych omawianego dokumentu. Przepis wymienia przykładowe elementy, które powinny się w nim znaleźć, o czym świadczy sformułowanie »w szczególności«" (G. Klimek: Komentarz do art. 79. W: Prawo geologiczne i górnicze. Komentarz. Red. B. Rakoczy. LEX 2015).

${ }_{18}$ Ibidem.

19 A. Lipiński: Komentarz do art. 6-9 ustawy z dnia 9 czerwca 2011 r. Prawo geologiczne i górnicze. „Prawne Problemy Górnictwa i Ochrony Środowiska” 2017, nr 1, s. 20.

${ }^{20}$ H. Schwarz: Prawo geologiczne i górnicze. Komentarz. T. 1: Art. 1-103. Salome, Wrocław 2013. 
tu, pod którego powierzchnią dane prace się odbywają. Konsekwentnie więc przyjąć należy, iż wykonanie dowolnego rodzaju roboty geologicznej skutkuje powstaniem obowiązku usunięcia powstałego zdegradowania lub zdewastowania gruntu, czyli przeprowadzenia rekultywacji. Można przeto postawić tezę, zgodnie z którą - niezależnie od użycia w treści art. 79 ust. 2 pr.g.g. zwrotu „W szczególności” - intencją ustawodawcy było, żeby prawidłowo sporządzony projekt robót geologicznych zawierał informacje na temat rekultywacji gruntów.

\section{Sposób rekultywacji}

$\mathrm{W}$ związku z przedstawionymi uwagami warto się również zastanowić, w jaki sposób powinna zostać opisana rekultywacja w treści właściwego projektu. W pierwszej kolejności należałoby się odwołać do treści art. 79 ust. 2 pkt 5 pr.g.g., zgodnie z którym projekt robót geologicznych powinien określać „,sposób rekultywacji gruntów”. W tym kontekście warto przypomnieć, że „określenie szczegółowych zasad sporządzania projektów robót geologicznych powierzono ministrowi właściwemu do spraw środowiska do uregulowania w rozporządzeniu"21. Wypada więc zauważyć, iż obowiązek zamieszczenia informacji na temat „sposobu rekultywacji gruntów” w projekcie robót geologicznych został także wskazany $\mathrm{w}$ treści ${ }^{22}$ - wydanego na podstawie art. 79 ust. 3 pr.g.g. - rozporządzenia Ministra Środowiska z dnia 20 grudnia 2011 r. w sprawie szczegółowych wymagań dotyczących projektów robót geologicznych, w tym robót, których wykonywanie wymaga uzyskania koncesji ${ }^{23}$. Pamiętając o zakazie wykładni per non est, należy podkreślić, iż - pomimo widocznej zbieżności normatywnej przepisów mówiących o tym obowiązku - żadna $\mathrm{z}$ owych regulacji nie jest zbędna. Trafne wydaje się natomiast założenie, zgodnie z którym powtórzenie normatywne służy uniknięciu niepewności co do obligatoryjnej treści projektu robót geologicznych. Uściślając: jednoznaczne wskazanie „sposobu rekultywacji" jako elementu projektu robót geologicznych w przepisie wspomnianego rozporządzenia ma na celu wyeliminowanie ewentualnych wątpliwości, jakie mogą powstawać w związku z zamieszczeniem w art. 79 ust. 2 pr.g.g. zwrotu „W szczególności”, o czym szerzej była mowa wcześniej.

Warto nadmienić również, że ustawodawca nie sprecyzował znaczenia zwrotu „sposób rekultywacji”. Odwołując się do rozważań zawartych w poprzednim rozdziale niniejszego artykułu, przyjąć należy, iż znaczenie owego sformułowa-

${ }^{21}$ M. Goss: Nadzór i regulacja sektora ropy i gazu. LEX 2016.

${ }^{22}$ Chodzi o $\S 1$ ust. 2 pkt 4 lit. d przywołanego rozporządzenia.

${ }^{23}$ Dz.U. 2011, nr 288, poz. 1696 ze zm. 
nia powinno się wyjaśniać w myśl postanowień u.o.g.r.l. Niemniej także w tej ostatniej ustawie nie został wyjaśniony zwrot „,sposób rekultywacji”; co więcej, w treści u.o.g.r.l. w ogóle się on nie pojawia. Wydaje się więc, że w celu wyjaśnienia tego zwrotu trzeba sięgnąć do sposobu jego uregulowania $\mathrm{w}$ treści postanowień pr.g.g., a następnie ustalić analogiczne rozwiązania w u.o.g.r.l. Ze względu na wspomniane milczenie ustawodawcy w kwestii wyjaśnienia „,sposobu rekultywacji” proponowana analiza nie może w pierwszej kolejności odwoływać się do ustawowego wyjaśnienia tego sformułowania. Stąd rozważania w przedmiotowym zakresie warto rozpocząć od zbadania kontekstu, w jakim „sposób rekultywacji” został ujęty w u.o.g.r.l. oraz pr.g.g.

W związku z powyższym zauważyć należy, iż „sposób rekultywacji” jako element projektu robót geologicznych podlega weryfikacji i zatwierdzeniu przez właściwy organ w trybie decyzji, a owo zatwierdzenie może mieć dwojaki charakter. $\mathrm{Z}$ treści art. 80 ust. 1 pr.g.g. wynika bowiem, iż może nastąpić w ramach rozstrzygnięcia o udzieleniu koncesji, jeżeli zaś nie jest ona wymagana w celu wykonywania planowanych robót geologicznych, to przedmiotowe zatwierdzenie następuje na mocy odrębnej decyzji administracyjnej. Co warto podkreślić, niezależnie od trybu zatwierdzania projektu robót geologicznych właściwe rozstrzygnięcie powinno zostać wydane przed podjęciem prac mogących wywierać negatywny wpływ na grunt.

Mechanizm zbliżony do opisanego tu zatwierdzania sposobu rekultywacji w ramach projektu robót geologicznych mają regulacje dotyczące wydawania decyzji administracyjnych odnoszących się bezpośrednio do poszczególnych aspektów samej rekultywacji, formułowane na gruncie postanowień u.o.g.r.l. Chodzi tutaj o wskazane w art. 22 ust. 1 rozstrzygnięcia, które określają:

1) stopień ograniczenia lub utraty wartości użytkowej gruntów, ustalony na podstawie opinii, o których mowa w art. 28 ust. 5;

2) osobę obowiązaną do rekultywacji gruntów;

3) kierunek i termin wykonania rekultywacji gruntów;

4) uznanie rekultywacji gruntów za zakończoną.

Ponadto do grona rozstrzygnięć w przedmiocie rekultywacji wydawanych na podstawie postanowień u.o.g.r.l. zaliczyć także należy decyzję administracyjną wymienioną w art. 20 ust. 6 u.o.g.r.l. Chodzi tutaj o decyzję, na podstawie której dokonywana jest zmiana podmiotu zobowiązanego do przeprowadzenia prac rekultywacyjnych.

W kontekście przedmiotu omawianych rozstrzygnięć trzeba zwrócić uwagę na pojęcie kierunku rekultywacji. W pozostałym bowiem zakresie rozstrzygnięcia, o których mowa w u.o.g.r.l., w widoczny sposób mają inny przedmiot aniżeli decyzje wydawane na podstawie postanowień pr.g.g. w celu zatwierdzenie sposobu rekultywacji. W pierwszej kolejności warto przywołać stanowisko, zgodnie z którym przez „kierunek rekultywacji” rozumieć należy „sposób i zakres koniecznych czynności rekultywacyjnych (technicznych, agrotechnicznych, 
nasadzeń) umożliwiających zagospodarowanie terenów po rekultywacji w określonym celu" 24 . W tym świetle przytoczenia wymaga słownikowe znaczenie wyrazu ,sposób":

„1) określony tryb postępowania, forma wykonania czegoś;

2) zespół cech charakterystycznych dla czyjegoś zachowania;

3) to, co umożliwia osiągnięcie lub wykonanie czegoś" 25 .

Na podstawie powyższego należałoby stwierdzić, że ustawowe pojęcia „kierunek” i „sposób” mają takie samo znaczenie. Wziąwszy jednak pod uwagę zakaz odwoływania się do rezultatów wykładni synonimicznej, założenie o tożsamości normatywnej obu pojęć trzeba odrzucić. W konsekwencji rekonstruowanie znaczenia „kierunku rekultywacji” oprzeć należy na drugim sposobie rozumienia owego pojęcia, który jest prezentowany w doktrynie. W tym ujęciu mówi się o kierunku rekultywacji w kontekście konkretnych celów działań rekultywacyjnych i wskazuje ich określone kierunki, np. rolny czy leśny ${ }^{26}$. Odwołując się do przytoczonej definicji słownikowej, można zatem stwierdzić, że pojęcia „,kierunek rekultywacji” i „sposób rekultywacji” mają nie tylko odmienne, lecz także rozdzielne zakresy znaczeniowe. Uwzględniwszy zarówno ten fakt, jak i wspomnianą już widoczną wprost odrębność zakresową pozostałych rozstrzygnięć w sprawie rekultywacji, które są wydawane na podstawie postanowień u.o.g.r.l., trzeba przyjąć, iż wydanie ani wszystkich owych rozstrzygnięć, ani też części z nich nie może być uznawane za określenie „sposobu rekultywacji”.

Nawiązując do ustawowej definicji pojęcia rekultywacji i do słownikowego znaczenia wyrazu „sposób”, można więc powiedzieć, że przez „sposób rekultywacji” rozumieć należy czynność albo zespół czynności, które mają prowadzić do przywrócenia lub zwiększenia wartości użytkowej bądź przyrodniczej gruntów, które zostały zdegradowane albo zdewastowane. Warto również zwrócić uwagę na to, iż kierunek rekultywacji jest wyznaczany dopiero po wystąpieniu degradacji albo zdewastowania gruntu, podczas gdy zatwierdzenie projektu robót geologicznych powinno nastąpić przed rozpoczęciem prac na danym terenie. Zważywszy więc zarówno na ten fakt, jak i na zestawienie znaczeń obu analizowanych pojęć, przyjąć należy, że rozstrzygnięcie w przedmiocie określenia sposobu rekultywacji determinuje treść decyzji wyznaczającej kierunek rekultywacji.

${ }^{24}$ W. Naworyta: Jeszcze raz krytycznie o kierunkach rekultywacji $i$ ich wyborze. „Prace Naukowe Instytutu Górnictwa Politechniki Wrocławskiej. Studia i Materiały” 2013, T. 136, nr 43 , s. 142.

${ }^{25}$ Słownik języka polskiego, strona WWW słowników PWN, [online:] https://sjp.pwn.pl/ szukaj/spos\%C3\%B3b.html [dostęp: 22.02.2021].

${ }^{26}$ Zob. A. Ostręga, R. Uberman: Kierunki rekultywacji i zagospodarowania - sposób wyboru, klasyfikacja i przykłady. „Górnictwo i Geoinżynieria” 2010, T. 34, z. 4, s. 445-461. 
Co istotne, zatwierdzenie „sposobu rekultywacji” w treści projektu robót geologicznych odróżnia zakres wykonywania administracyjnego nadzoru nad pracami rekultywacyjnymi wymaganymi ze względu na postanowienia pr.g.g. od uprawnień organów administracyjnych w odniesieniu do rekultywacji prowadzonej na zasadach ogólnych (tj. wyłącznie na podstawie u.o.g.r.l.). Jak bowiem zaznaczono wcześniej, w przypadku gdy wykonywanie obowiązku rekultywacyjnego podlega jedynie regulacjom u.o.g.r.l., wybór poszczególnych prac należy wyłącznie do sprawcy zdegradowania albo zdewastowania gruntu. Natomiast podmiot zobowiązany do przeprowadzenia rekultywacji na podstawie postanowień pr.g.g. jest związany treścią projektu robót geologicznych w zakresie wskazanych w tym dokumencie prac rekultywacyjnych.

\section{Termin rekultywacji}

Jak nadmieniono, w treści projektu robót geologicznych powinna się znaleźć również informacja na temat terminu rekultywacji; prawodawca nie wskazał jednak wprost, o jaki okres chodzi. Dlatego przypomnieć należy, że obowiązek jej przeprowadzenia pojawia się dopiero w momencie naruszenia wartości użytkowej gruntu, a wiążący moment rozpoczęcia prac rekultywacyjnych jest zależny od wydania decyzji, o których mowa w art. 22 ust. 1 u.o.g.r.l. W konsekwencji owe prace stanowią zdarzenie przyszłe, którego moment początkowy nie może być znany w trakcie zatwierdzania projektu robót geologicznych, toteż „termin” nie oznacza chwili rozpoczęcia ani zakończenia prac rekultywacyjnych. W związku z tym warto zauważyć, że prawodawca wspomina o konieczności umieszczenia analizowanego ,terminu” w tej samej jednostce redakcyjnej, w której jest mowa o sposobie rekultywacji. Odwoławszy się do argumentum a rubrica, można zatem przyjąć, iż przez pojęcie „termin rekultywacji” rozumieć należy okres, w którym powinny zostać wykonane prace rekultywacyjne. Wskazać jednocześnie trzeba, iż $\mathrm{w}$ świetle orzecznictwa maksymalnym terminem na wykonanie rekultywacji jest okres pięcioletni ${ }^{27}$. Przedstawione stanowisko wynika z art. 20 ust. 4 u.o.g.r.l., który zgodnie z treścią art. 129 pr.g.g. znajduje odpowiednie zastosowanie do regulacji pr.g.g.

Warto również przywołać ponownie art. 22 ust. 1 u.o.g.r.l., gdyż zgodnie $\mathrm{z}$ tym przepisem rozstrzygnięcia takie jak ustalenie terminu rekultywacji zapadają co do zasady po zakończeniu działalności prowadzącej do zdegradowania albo zdewastowania gruntu. $\mathrm{Z}$ kolei skoro zatwierdzenie projektu robót

${ }^{27}$ Wyrok WSA we Wrocławiu z dnia 3 marca 2020 r., sygn. II SA/Wr 808/19, Legalis nr 2307974. 
geologicznych następuje przed wydaniem wspomnianej decyzji, można byłoby powiedzieć, iż wydanie rozstrzygnięcia na podstawie art. 22 ust. 1 pkt 3 u.o.g.r.l. jest zbędne, ponieważ czas na wykonanie rekultywacji został już wyznaczony. Ta teza nie pozostaje $\mathrm{w}$ sprzeczności z treścią art. 129 pr.g.g., ponieważ ów przepis stanowi o odpowiednim, a nie bezpośrednim stosowaniu postanowień w przedmiocie rekultywacji.

Przeciwko temu stanowisku przemawiają okoliczności o charakterze faktycznym. Otóż zatwierdzenie projektu robót geologicznych następuje przed podjęciem działań mogących negatywnie oddziaływać na grunt. Stąd na tym etapie niejednokrotnie trudno przewidzieć poziom degradacji albo zdewastowania gruntów, a w konsekwencji trudno również odgórnie określić czas potrzebny na przeprowadzenie prac rekultywacyjnych. W związku z tym wydanie rozstrzygnięcia $\mathrm{w}$ przedmiocie terminu rekultywacji już po zakończeniu czynności prowadzących do degradacji albo zdewastowania, czyli na podstawie art. 22, mogłoby skutkować swoistym urealnieniem czasu wyznaczonego na usunięcie szkód. Warto jednak zauważyć, iż w takim ujęciu rozstrzyganie o terminie rekultywacji na etapie zatwierdzania projektu robót geologicznych staje się w dużej mierze iluzoryczne. Można nawet w pewnym sensie mówić o zbędności zamieszczania informacji o terminie rekultywacji w projekcie robót geologicznych, skoro i tak właściwy okres miałby być wyznaczany dopiero w trybie decyzji wydawanej na podstawie art. 22 ust. 1 pkt 3 u.o.g.r.l. Należy również podkreślić, iż w przypadkach gdy projekt plac geologicznych jest zatwierdzony odrębną decyzją, dopuszczenie do wydania rozstrzygnięcia w oparciu o u.o.g.r.l. stanowiłoby akceptację stanu, w którym zakres związania jedną decyzją administracyjną mógłby być modyfikowany przez inne rozstrzygnięcie. Toteż warto zauważyć, iż ze względu na regulację art. 8 Kodeksu postępowania administracyjnego można byłoby oczekiwać, iż rozstrzygnięcie wydawane $\mathrm{w}$ oparciu o u.o.g.r.l. będzie z zasady powielało termin rekultywacji określony w projekcie robót geologicznych. Przedstawione konsekwencje zdają się więc przemawiać za odrzuceniem koncepcji, zgodnie z którą termin rekultywacji miałby być określany dwukrotnie.

\section{Podsumowanie}

Przeprowadzone rozważania skłaniają do przyznania, że ustawodawca de facto nakazuje przygotowanie całościowego planu prac rekultywacyjnych jeszcze przed rozpoczęciem właściwych robót geologicznych. W ramach projektu owych robót powinien zostać sprecyzowany sposób rekultywacji, przez co należy rozumieć zarówno rodzaj, jak i kolejność prac rekultywacyjnych. Ponadto 
podmiot planujący rozpoczęcie robót geologicznych powinien, zanim do nich przystąpi, określić spodziewany czas niezbędny, żeby usunąć zdewastowanie albo zdegradowanie gruntu.

Niezależnie od powyższego zaakcentowania wymagają liczne słabości analizowanych przepisów. W pierwszej kolejności wspomnieć należy o niewłaściwym doborze zwrotów używanych w poszczególnych regulacjach, czego najwyrazistszym przykładem jest użycie zwrotu „w szczególności” w art. 79 ust. 2 pr.g.g., które może powodować wątpliwości co do obowiązku zamieszczenia informacji na temat rekultywacji w treści projektu robót geologicznych. Innym mankamentem analizowanego tekstu prawnego są zaniechania ustawodawcy w wyjaśnianiu zastosowanych pojęć (np. „sposób rekultywacji” czy „kierunek rekultywacji”).

\section{Literatura}

Bednorz J.: Społeczno-ekologiczne skutki eksploatacji węgla kamiennego w Polsce. „Górnictwo i Geologia" 2011, T. 6, z. 4, s. 5-17.

Bieluk J.: Komentarz do art. 4. W: Ustawa o ochronie gruntów rolnych i leśnych. Komentarz. Red. J. Bieluk, D. Łobos-Kotowska. Legalis 2015.

Ciechanowicz-McLean J., Wysokińska K.: Prawna ochrona gruntów rolnych i leśnych. W: Administracja a środowisko. Prace dedykowane prof. zw. dr. hab. Markowi Górskiemu z okazji jubileuszu 45-lecia pracy naukowej. Red. A. Barczak, P. Korzeniowski. Wydawnictwo Naukowe Uniwersytetu Szczecińskiego, Szczecin 2018, s. 157-172.

Czech E.K.: Obowiazki rekultywacji i remediacji powierzchni ziemi jako obowiazki wynikajace z mocy samego prawa - ocena istniejacych i proponowanych rozwiazań prawnych. W: Prawne aspekty gospodarowania zasobami środowiska. Oddziaływanie na zasoby środowiska. Red. B. Rakoczy, M. Szalewska, K. Karpus. TNOiK „Dom Organizatora”, Toruń 2014, s. 195-203.

Goss M.: Nadzór i regulacja sektora ropy i gazu. LEX 2016.

Kaźmierczak U.: Efektywność waloryzacji terenów poeksploatacyjnych górnictwa skalnego. Politechnika Wrocławska, Wrocław 2019.

Klimek G.: Komentarz do art. 79. W: Prawo geologiczne i górnicze. Komentarz. Red. B. Rakoczy. LEX 2015.

Korzeniowski P.: Cele i funkcje ochrony prawnej gruntów rolnych i leśnych. „Prawo i Środowisko" 2012, nr 3, s. 111-124.

Lipiński A.: Komentarz do art. 6-9 ustawy z dnia 9 czerwca 2011 r. Prawo geologiczne i górnicze. „Prawne Problemy Górnictwa i Ochrony Środowiska” 2017, nr 1, s. 11-31.

Mikosz R.: Odpowiedzialność za szkody wyrządzone ruchem zakładu górniczego. Wolters Kluwer, Zakamycze 2006.

Naworyta W.: Jeszcze raz krytycznie o kierunkach rekultywacji i ich wyborze, „Prace Naukowe Instytutu Górnictwa Politechniki Wrocławskiej. Studia i Materiały" 2013, T. 136, nr 43, s. $141-155$. 
Ostręga A., Uberman R.: Kierunki rekultywacji i zagospodarowania - sposób wyboru, klasyfikacja i przykłady, „Górnictwo i Geoinżynieria” 2010, T. 34, z. 4, s. 445-461.

Ptak M., Kasztelewicz Z.: Proces likwidacji, rekultywacji w odkrywkowych zakładach górniczych a wykorzystanie odpadów wydobywczych, innych niz wydobywcze oraz surowców antropogenicznych. „Górnictwo Odkrywkowe” 2016, R. 57, nr 1, s. 40-46.

Prusinkiewicz Z., Kowalkowski A., Królikowski L.: Ochrona i rekultywacja gleb leśnych, „Roczniki Gleboznawcze” 1983, T. 34, nr 3, s. 185-201.

Radecki W.: Rekultywacja zanieczyszczonej ziemi. „Ochrona Środowiska. Prawo i Polityka” 2007, nr 3 (49), s. 49-53.

Schwarz H.: Prawo geologiczne i górnicze. Komentarz. T. 1: Art. 1-103. Salome, Wrocław 2013.

Trzcińska D.: Szkoda w środowisku zaistniała przed wejściem w życie ustawy z 13 kwietnia 2007 r. o zapobieganiu szkodom w środowisku i ich naprawie. W: Prawne aspekty gospodarowania zasobami środowiska. Oddziatywanie na zasoby środowiska. Red. B. Rakoczy, M. Szalewska, K. Karpus. TNOiK „Dom Organizatora”, Toruń 2014, s. 109-130.

Walas M.: Administracja geologiczna i górnicza. W: Wybrane problemy prawa geologicznego i górniczego. Red. B. Rakoczy. LEX 2016.

Wojtulek P., Kocowski T., Małecki W.: Prawo geologiczne i górnicze. Wydawnictwo C.H. Beck, Warszawa 2020.

Orzecznictwo

Wyrok NSA z dnia 13 lutego 2019 r., sygn. II OSK 641/17, Legalis nr 1889827.

Wyrok WSA w Gliwicach z dnia 15 stycznia 2010 r., sygn. II SA/Gl 1334/08, Legalis nr 380970.

Wyrok WSA we Wrocławiu z dnia 3 marca 2020 r., sygn. II SA/Wr 808/19, Legalis nr 2307974.

Łukasz Dubiński

\section{Reclamation in a geological work project}

\section{Summary}

The considerations focus on the principles of determining the manner of carrying out reclamation in the so-called geological work project. We are talking about a document that is subject to approval before commencing geological works. Therefore, the aim of the text is to present the plan of actions required by the legislator to be undertaken after the end of the activity leading to the devastation or degradation of the land as a result of the activity regulated by the provisions of the Geological and Mining Law.

Key words: reclamation, land, project, mining 
Лукаш Дубиньский

\section{Рекультивация в плане геологических работ}

Резюме

Основные рассуждения посвящены правилам определения способа проведения рекультивации в рамках так называемого плана геологических работ. Речь идет о документе, подлежащему утверждению до начала геологических работ. Поэтому в тексте речь идет о представлении плана действий, требуемого законодателем, которые должны быть предприняты после окончания деятельности, ведущей к опустошению или деградации земель в результате деятельности, регулируемой положениями закона о геологическом и горном праве.

Ключевые слова: рекультивация, земельный участок, план, добыча полезных ископаемых

Łukasz Dubiński

\section{Bonifica in un progetto di opere geologiche}

\section{Sommario}

La discussione si concentra sulle regole di specificazione del modo di ricoltivazione nel cosiddetto progetto di opere geologiche. Stiamo parlando di un documento che è soggetto ad approvazione prima di iniziare i lavori geologici. Il testo riguarda quindi, la presentazione di un piano di attività richiesto dal legislatore, si tratta di azioni da intraprendere dopo la cessazione delle attività che portano alla devastazione o al degrado del territorio a seguito delle attività regolate dalle disposizioni della legge geologica e mineraria.

Parole chiave: ricoltivazione, terra, progetto, minerario 